\title{
HUBUNGAN AKTIVITAS FISIK DENGAN KADAR ASAM URAT DI RW 13 KAMPUNG MOKLA, KECAMATAN PARONGPONG
}

\author{
Natania ${ }^{1}$, Evelin Malinti ${ }^{2}$ \\ ${ }^{1,2}$ Fakultas Ilmu Keperawatan, Universitas Advent Indonesia \\ Email : nataniaoctober98@gmail.com
}

\begin{abstract}
Abstrak
Peningkatan asam urat darah menjadi tanda perubahan fungsi metabolic dan hemodinamik. Faktor yang berkontribusi terhadap peningkatan produksi asam urat adalah konsumsi makanan yang banyak mengandung purin dan asam urat, obesitas, penggunaan obat, aktivitas fisik dan penyakit tertentu dalam darah. Penelitian ini dilakukan dengan tujuan untuk mengetahui adanya hubungan antara aktivitas fisik dengan kadar asam urat. Jenis penelitian adalah analisis deskriptif dengan pendekatan cross sectional. Jumlah subjek pada penelitian ini adalah 71 orang dewasa laki-laki dan perempuan dengan rentang usia 2545 tahun. Sampel dipilih dengan metode convenience sampling. Data meliputi karakteristik responden, aktivitas fisik tujuh hari terakhir, dan kadar asam urat. Aktivitas fisik diperoleh melalui pengisian international physical activity questionnaire (IPAQ). Pemeriksaan kadar asam urat menggunakan alat ukur digital NESCO MultiCheck serta test strip uric acid. Data dianalisis menggunakan Chi-Square Test. Hasil penelitian menunjukkan tidak ada hubungan yang signifikan antara aktivitas fisik dengan kadar asam urat (p>.05). Kesimpulan, tidak terdapat hubungan yang signifikan antara tingkat aktivitas fisik dengan kadar asam urat. Pada penelitian ini faktor yang mempengaruhi kadar asam urat adalah variabel yang tidak diteliti. Saran yang dapat diberikan kepada peneliti berikutnya ialah penggunaan metode purposive sampling, melakukan perhitungan calon sampel secara menyeluruh, serta mempertimbangkan variabel lain seperti pola makan, tekanan darah, status gizi, indeks massa tubuh.
\end{abstract}

Kata Kunci: Asam Urat, Aktivitas Fisik

\section{Abstract}

Increased blood uric acid is a sign of changes in metabolic and hemodynamic function. Factors that contribute to increased uric acid production are consumption of foods high in purines and uric acid, obesity, drug use, physical activity and certain diseases in the blood. This research was conducted with the aim of knowing the relationship between physical activity and uric acid levels. This type of research is a descriptive analysis with a cross sectional approach. The number of subjects in this study were 71 adult men and women with an age range of 25-45 years. The sample was selected by convenience sampling method. The data includes the characteristics of the respondents, physical activity for the last seven days, and uric acid levels. Physical activity was obtained by filling in an international physical activity 
questionnaire (IPAQ). Examination of uric acid levels used a digital NESCO MultiCheck measuring instrument and a uric acid test strip. Data were analyzed using the Chi-Square Test. The results showed that there was no significant relationship between physical activity and uric acid levels ( $p>.05)$. In conclusion, there is no significant relationship between physical activity levels and uric acid levels. In this study, the factors that influence uric acid levels are variables that are not examined. Suggestions that can be given to the next researcher are the use of purposive sampling method, carry out a comprehensive calculation of prospective samples, and consider other variables such as diet, blood pressure, nutritional status, body mass index.

Keyword: Uric Acid, Physical Activity

\section{PENDAHULUAN}

Kadar asam urat darah yang tinggi telah sejak lama diketahui menjadi penyebab gout, dan peningkatan asam urat juga menjadi tanda dari gangguan metabolik dan hemodinamik. Bahkan beberapa penelitian menyebutkan bahwa hiperurisemia meningkatkan angka kematian pada gangguan kardiovaskular. Kejadian hiperurisemia mengalami peningkatan pada pria usia >30 tahun serta pada wanita yang telah mencapai fase menopause (Fauzi, 2018; Lohr, 2018).

Dua kondisi yang dapat membuat peningkatan kadar asam urat dalam darah, yaitu tinggi purin yang dihasilkan serta pengeluaran asam urat yang rendah, yang menyebabkan keseimbangan purin dalam tubuh menjadi terganggu (Darmawan et al., 2016). Kadar asam urat dalam tubuh dihasilkan dari pembentukan purin yang merupakan salah satu unsur dari asam nukleat. Penumpukan kristal di persendian disebabkan oleh meningkatnya kandungan asam urat dalam darah senilai $0,5-0,75 \mathrm{~g} / \mathrm{ml}$ (Jaliana et al., 2018). Gout yang telah kronis dan tanpa penanganan dapat mengakibatkan kondisi yang lebih buruk. Rasa sakit akibat serangan asam urat juga bisa mengganggu jalan kaki, pekerjaan rumah dan aktivitas sehari-hari lainnya. Selain itu kerusakan sendi akibat serangan asam urat yang berulang kali dapat menyebabkan kecacatan permanen. Masalah seperti tophi, deformitas sendi, penyakit ginjal, penyakit jantung, serta kondisi lain seperti katarak, sindrom mata kering, dan kristal asam urat di paru-paru (Healthline.com, 2018).

Pada 2015-2016, prevalensi asam urat adalah 3,9\% di antara orang dewasa di AS (9,2 juta orang), dengan 5,2\% (5,9 juta jiwa) pada pria dan 2,7\% (3,3 juta jiwa) pada wanita. Kadar asam urat rata-rata adalah $6,0 \mathrm{mg} / \mathrm{dl}$ pada pria dan 4,8 mg / dl pada wanita, dan tingkat prevalensi hiperurisemia masing-masing adalah 20,2\% dan 20,0\%(Chen-xu et al., 2019). Prevalensi penyakit sendi di Indonesia sebesar 7,3\%, terdiri dari 6,1\% pada pria dan $8,5 \%$ pada wanita (Kemenkes RI, 2018). Sedangkan di Jawa Barat prevalensi 
penyakit sendi tahun 2018 sebesar 8,86\% (52.511 jiwa) dan sebesar 5,91\% (1.783 jiwa) di Kabupaten Bandung Barat (Balitbangkes, 2018).

Faktor yang berkontribusi terhadap peningkatan produksi asam urat ialah tingginya konsumsi makanan kaya purin dan asam urat, obesitas, penggunaan obat, aktivitas fisik dan penyakit tertentu dalam darah (Kusumayanti et al., 2017). Gangguan kesehatan metabolik terjadi oleh karena rendahnyat tingkat aktivitas fisik (Darmawan et al., 2016). Hal ini menyebabkan terjadinya kondisi insulin yang tidak bekerja secara normal, yang mengakibatkan terhambatnya pengeluaran asam urat melalui urin.

Aktivitas fisik yang diajurkan dapat dilakukan dengan dengan menerapkan BBTT (baik, benar, terukur, dan teratur). Baik artinya, aktivitas cocok dengan kondisi dan kemampuan fisik. Benar yaitu, melakukan aktivitas secara bertahap dari pemanasan hingga pendinginan. Terukur adalah melakukan aktivitas sesuai dengan intensitas dan waktu yang telah diukur. Yang terakhir, teratur berarti aktivitas dilakukan secara rutin 3 hingga 5 waktu dalam 1 minggu (Kemenkes RI, 2018).

Beberapa penelitian terdahulu telah dilakukan menunjukkan bahwa aktifitas fisik berpengaruh pada tingkat asam urat (Astari et al., 2018; Fauzi, 2018; Jamila, 2018; Pusriningsih, 2015). Penelitian mengenai asam urat di Indonesia telah banyak dilakukan dan memperoleh hasil penelitian yang variatif. Sehingga peneliti ingin lebih lanjut meneliti salah satu faktor yang memiliki hubungan dengan asam urat yaitu aktivitas fisik.

\section{BAHAN DAN METODE PENELITIAN}

Penelitian ini menggunakan model analisis descriptive analytical, serta menggunakan pendekatan cross sectional yang bertujuan untuk mengetahui tingkat hubungan sebab akibat dari tingkat aktivitas fisik dan serum asam urat. Populasi pada penelitian ini merupakan warga yang tinggal di RW 13, Kampung Mokla, Desa Cihanjuang Rahayu Kecamatan Parongpong. Penelitian ini menggunakan non-probability sampling sebagai teknik pengambilan sampel, yaitu convenience sampling. Metode tersebut ialah yang paling cocok dengan penelitian ini, dikarenakan convenience sampling merupakan pengambilan sampel yang sangat sederhana dengan mengambil unit pengamatan yang dijumpai atau yang sedapatnya saja (Asra, 2015). Populasi tersebut diseleksi berdasarkan beberapa kriteria, sebagai berikut: umur responden dilihat berdasarkan rata-rata berkisaran 25-45 tahun; jenis kelamin laki-laki atau perempuan; responden tidak mengkonsumsi obat penurun asam urat dalam waktu dekat; responden yang memiliki aktivitas fisik ringan, sedang dan berat dalam jangka waktu satu minggu terakhir.

Tujuan penelitian dijelaskan kepada responden sebelum melakukan pengambilan data. Responden berpartisipasi atas kemauan sendiri tanpa ada paksaan dengan menandatangani informed consent. Prosedur 
pengumpulan data termasuk pengukuran tingkat aktivitas fisik maupun pemeriksaan asam urat. Pengumpulan data dilakukan dengan melakukan pengukuran tingkat aktivitas fisik dengan melakukan wawancara dengan pengisian kuesioner pada setiap responden dan pemeriksaan kadar asam urat. Tingkat aktivitas fisik diukur menggunakan kuesioner yang berisi pertanyaan mengenai aktivitas fisik yang dilakukan dalam rentang waktu 7 hari. Kuesioner yang digunakan dalam penelitian ini yaitu International Physical Activity Questionnaire (IPAQ) yang telah diterjemahkan kedalam bahasa Indonesia. Hasil uji reliabilitas yang dilakukan sebelumnya menunjukkan IPAQ memiliki reliabilitas yang tinggi > 0.9 (Hastuti, 2013). Hasil pengukuran tingkat aktivitas kemudian dihitung berdasarkan rumus IPAQ yang telah ditetapkan pada file IPAQ jenis Microsoft Excel untuk mendapatkan hasil tingkat aktivitas fisik masing-masing responden. Berdasarkan IPAQ, ada 3 tingkat aktivitas fisik, yaitu Rendah yang diberikan skor 1, Moderat yang diberikan skor 2, dan Tinggi yang diberikan skor 3. Selanjutnya kadar asam urat responden akan diukur menggunakan NESCO MultiCheck serta test strip uric acid.

Data yang terkumpul dianalisa untuk mencari frekuensi, data demografi, tingkat aktivitas fisik dan asam urat. Analisa hubungan antara kedua variable tersebut dilakukan dengan Chi-Square Test.
Jumlah responden yang digunakan pada penelitian ini sebanyak 71 responden dengan rentang usia 25-45 tahun. Terdiri dari 24 pria dan 47 wanita, dengan latar belakang yang berbeda. Terdiri dari 38 orang ibu rumah tangga (IRT), 16 orang petani, 3 orang karyawan, serta 14 orang wiraswasta. Karakterisktik responden ditunjukkan pada tabel dibawah.

Tabel 1. Karakteristik Responden: Jenis Kelamin dan Pekerjaan

\begin{tabular}{ccc}
\hline Karakteristik & N & \% \\
\hline Jenis Kelamin & & \\
Wanita & 47 & 66,2 \\
Pria & 24 & 33,8 \\
\hline Pekerjaan & & \\
IRT & 38 & 53,5 \\
Petani & 16 & 22,5 \\
Karyawan & 3 & 4,2 \\
Wiraswasta & 14 & 19,7 \\
\hline
\end{tabular}

Berdasarkan tabel 2 responden dengan aktivitas kategori rendah sebanyak 2 orang, kategori sedang sebanyak 13 orang, dan kategori tinggi sebanyak 56 orang. Untuk kadar asam urat, sebanyak 53 responden berada pada kategori normal dan sebanyak 18 responden dalam kategori tinggi. Gambaran tentang tingkat aktivitas fisik dan kadar asam urat responden tersebut ditunjukkan pada tabel 2.

HASIL 
Tabel 2. Tingkat Aktivitas Fisik dan Kadar

Asam Urat

\begin{tabular}{lcc}
\hline \multicolumn{1}{c}{ Kategori } & N & \% \\
\hline Tingkat Aktivitas Fisik & & \\
Rendah & 2 & 2,8 \\
Sedang & 13 & 18,3 \\
Tinggi & 56 & 78,9 \\
\hline$\quad$ Kadar Asam Urat & & \\
Normal & 53 & 74,6 \\
Tinggi & 18 & 25,4 \\
\hline
\end{tabular}

Berikut ini hasil analisis crosstab antara

ke-dua variabel. Analisis crosstab ini dilakukan dengan menyajikan data variabel aktivitas fisik dan data variabel asam urat secara silang hubungan antara kedua dapat terlihat.

Tabel 3. Hubungan Aktivitas Fisik dengan Asam Urat

\begin{tabular}{ccccc}
\hline Aktivita & \multicolumn{2}{c}{ Asam Urat } & & \\
s Fisik & Norma & Tingg & $\boldsymbol{X}^{2}$ & $\boldsymbol{P}$ \\
& $\mathbf{l}$ & $\mathbf{i}$ & & \\
\hline Rendah & 1 & 1 & & \\
Sedang & 10 & 3 & 0.681 & 0.71 \\
Tinggi & 42 & 14 & & 1 \\
\hline
\end{tabular}

Berdasarkan tabel 3, responden dengan tingkat aktivitas fisik low (rendah) memiliki nilai asam urat normal sebanyak 1 responden, dan nilai asam urat tinggi sebanyak 1 responden. Responden dengan tingkat aktivitas fisik moderate (sedang) memiliki nilai asam urat normal sebanyak 10 responden dan nilai asam urat tinggi sebanyak 3 responden. Responden dengan tingkat aktivitas fisik high (tinggi) memiliki nilai asam urat normal sebanyak 42 dan nilai asam urat tinggi sebanyak 14 responden.

Hasil penelitian setelah dilakukan uji Chi-Square test mendapatkan nilai $\mathrm{X}^{2}$ sebesar 0,681 dengan nilai $\mathrm{p}$ sebesar 0.711 sehingga nilai $\mathrm{p}>$ 0.05. Berdasarkan uji statistik dapat ditemukan bahwa tidak terdapat hubungan yang signifikan antara tingkat aktivitas fisik dengan kadar asam urat pada warga RW 13, Kampung Mokla, Desa Cihanjuang Rahayu, Kecamatan Parongpong.

\section{PEMBAHASAN}

Berdasarkan penelitian yang telah dilakukan, didapatkan bahwa hasil tingkat aktivitas fisik kebanyakan reponden memiliki aktifitas tinggi, dengan nilai asam urat normal, Hanya sebagian kecil responden mempunyai nilai asam urat tinggi. Walaupun uji hubungan tidak menunjukkan hasil yang siknifikan, dapat di asumsikan bahwa asam urat normal yang dimiliki responden merupakan hasil dari aktifitas fisik yang tinggi dan faktor lain yang mungkin mempengaruhi.

Hasil pengujian hubungan antara aktivitas fisik dengan kadar asam urat pada penelitian ini sejalan dengan penelitian-penelitian sebelumnya. Penelitian pada subjek lansia menyatakan bahwa beberapa faktor dan aktifitas fisik termasuk olahraga tidak berhubungan dengan asam urat (Purnasari et al, 2019). Penelitian lain menunjukkan hal yang sama pada responden usia 20-44 tahun, menyatakan bahwa 
aktivitas fisik tidak memiliki pengaruh pada kejadian asam urat (Jaliana et al., 2018). Penelitian yang dilakukan pada pasien rawat jalan menunjukkan bahwa aktivitas fisik dengan kadar asam urat tidak memilki hubungan (Nurhamidah \& Nofiani, 2015).

Penelitian lain pada orang dewasa sehat menyatakan bahwa kurang aktifitas fisik dalam hal ini memiliki gaya hidup sedentary selama lebih dari 10 hari cenderung mengalami peningkatan asam urat. Sedangkan subjek penelitian yang terlibat dalam upaya kesehatan meningkatkan aktifitas fisik ditemukan memiliki kadar asam urat yang rendah (Yong Park et al., 2019). Hiperurisemia meningkatkan angka mortalitas sehingga perlu penanganan serius. Namun disayangkan pengobatan banyak membawa efek samping, sedangkan aktifitas fisik diketahui dapat memperpanjang hidup penderita hiperurisemia. Sehingga aktifitas fisik merupakan alternative pilihan untuk menurunkan serum asam urat (Yong Park et al., 2019).

Peran aktifitas fisik dan olahraga dalam mempengaruhi kadar asam urat dikaitkan dengan asam laktat. Saat melakukan aktifitas olahraga, asam laktat akan dihasilkan. Peningkatan asam laktat tersebut dapat menyebabkan penurunan pengeluaran asam urat. Peningkatan asam laktat tersebut hanya terjadi sementara saja dan beberapa jam kemudian asam laktat kembali pada kadar normal. Oleh sebab itu, tidak menutup kemungkinan bahwa responden yang tercatat memiliki aktivitas fisik tinggi dalam satu minggu terakhir, memiliki kadar asam urat normal
(Yenrina, 2014). Hiperurisemia pada seseorang dengan berat badan lebih dapat dicegah dengan melakukan aktivitas fisik moderat, serta dapat juga mencegah peningkatan berat badan dan juga keseimbangan metabolisme dapat ditingkatkan. Sebagaimana disebutkan oleh penelitian sebelumnya bahwa obesitas berhubungan erat dengan kejadian hiperurisemia (Leokuna \& Malinti, 2020). Metabolism otot meningkat saat melakukan aktifitas. Hal ini menyebabkan menurunnya resiko gangguan metabolic mencegah berbagai penyakit yang berhubungan dengan sindrom metabolik (Dayana, 2015).

\section{KESIMPULAN}

Penelitian ini menunjukkan bahwa tidak terdapat hubungan yang signifikan antara tingkat aktivitas fisik dengan kadar asam urat. Kadar asam urat dapat dipengaruhi oleh beberapa faktor, namun pada penelitian ini didapati bahwa tingkat aktivitas fisik bukan menjadi faktor yang mempengaruhi, dan faktor yang mempengaruhi adalah variabel yang tidak diteliti.

\section{SARAN}

Saran yang dapat peneliti berikan untuk peneliti berikutnya di masa mendatang ialah penggunaan metode purposive sampling, melakukan perhitungan calon sampel secara menyeluruh sehingga akan terlihat bagaimana variabel saling mempengaruhi dengan jelas, serta mempertimbangkan variabel lain untuk diteliti seperti pola makan, tekanan darah, status gizi, 
indeks massa tubuh (IMT), dan lain-lain. Saran berikutnya yang dapat peneliti sampaikan bagi masyarakat, untuk tetap menjaga keseimbangan antara kadar asam urat melalui makanan yang dikonsumsi dengan aktivitas fisik yang dilakukan.

\section{REFERENSI}

Asra. (2015). Metode Penelitian Survei. InMedia.

Astari et al. (2018). Faktor-Faktor Yang

Mempengaruhi Kadar Asam Urat Pada

Usia Produktif di Desa Nongan,

Kabupaten Karangasem. BMJ. Vol 5(2),

134-142.

https://doi.org/https://doi.org/10.36376/bmj .$v 5 i 2.43$

Balitbangkes. (2018). Laporan Riset Kesehatan

Dasar Jawa Barat 2018.

https://www.kemkes.go.id/resources/downl oad/info-terkini/hasil-riskesdas-2018.pdf

Chen-xu, M., Yokose, C., Rai, S. K., Pillinger,

M. H., \& Choi, H. K. (2019).

Contemporary Prevalence of Gout and

Hyperuricemia in the United States and

Decadal Trends : The National Health and

Nutrition Examination Survey, 2007 -

2016. Arthritis \& Rheumatology, 71(6),

991-999. https://doi.org/10.1002/art.40807

Darmawan, P. S., Kaligis, S. H. M., \& Assa, Y.

A. (2016). Gambaran Kadar Asam Urat

Darah Pada Pekerja Kantor. Jurnal E-

Biomedik, 4(2).

https://doi.org/10.35790/ebm.4.2.2016.146
15

Dayana, B. (2015). Hubungan Antara Intensitas Aktivitas Fisik dan Kadar Asam Urat Serum Pada Populasi Sindrom Metabolik. Media Medika Muda, 4(3), 218-228. https://www.neliti.com/publications/13903 0/hubungan-antara-intensitas-aktivitasfisik-dan-kadar-asam-urat-serum-padapopula\#cite

Fauzi, M. (2018). Hubungan Aktifitas Fisik Dengan Kadar Asam Urat Di Padukuhan Bedog Trihanggo Gamping Sleman Yogyakarta. Ilmu Keperawatan. http://digilib.unisayogya.ac.id/id/eprint/437 3

Hastuti, J. (2013). Anthropometry and Body Composition of Indonesian Adults: An Evaluation of Body Image, Eating Behaviours, and Physical Activity. Hypertension, 6, II71-5. https://eprints.qut.edu.au/61740/ Healthline.com. (2018). Gout Complications. www.healthline.com/health/goutcomplications

Jaliana, Suhadi, \& Sety, L. O. M. (2018). Faktor-Faktor Yang Berhubungan Dengan Kejadian Asam Urat Pada Usia 20-44 Tahun di RSUD Batheramas Provinsi Sulawesi Tenggara Tahun 2017.

Jimkesmas, 3(2), 1-13. http://ojs.uho.ac.id/index.php/JIMKESMA S/article/download/3925/3003 Jamila. (2018). Hubungan Gaya Hidup Dengan Kadar Asam Urat Pada Usia Produktif di 
Posbindu PTM Desa Sumbertebu

Kecamatan Bangsal Kabupaten Mojokerto.

Journal of Linguistics, 3(2), 139-157.

https://doi.org/10.18041/2382-

3240/saber.2010v5n1.2536

Kemenkes RI. (2018). Mengenal Jenis Aktivitas

Fisik.

https://promkes.kemkes.go.id/content/?p=8

807

Kusumayanti, G. A. D., Ni, ;, \& Dewantari, M.

(2017). The Influence of Low Purine Diet and Physical Activity on Changing of Uric

Acid Levels in Hyperuricemia.

International Journal of Health Sciences,

1(3), 1-9.

https://doi.org/10.21744/ijhs.v1i3.45

Leokuna, W. I., \& Malinti, E. (2020). Hubungan

Indeks Massa Tubuh dengan Kadar Asam

Urat pada Orang Dewasa di Oesapa Timur.

Nursing Inside Community, 2, 94-99.

http://jurnal.stikesnh.ac.id/index.php/nic/ar ticle/view/342

Lohr, J. W. (2018). Hyperuricemia. MedScape. https://emedicine.medscape.com/article/24 1767-overview\#a4

Nurhamidah, N., \& Nofiani, S. (2015). Faktor-

Faktor Yang Berhubungan Dengan

Kejadian Asam Urat Pada Pasien Rawat

Jalan Di Rumah Sakit Stroke Nasional

Bukittinggi Tahun 2015. Jurnal Kesehatan

Perintis, 2(4), 240097.

https://www.neliti.com/publications/24009

7/faktor-faktor-yang-berhubungan-dengankejadian-asam-urat-pada-pasien-rawat- jalan

Purnasari et al. (2019). Faktor-Faktor yang

Berhubngan dengan Kadar Asam Urat

pada Lansia di Posbindu Sedap Malam

Desa Cikarawang. February, 1-9.

https://doi.org/.1037//0033-2909.I26.1.78

Pusriningsih, S. S. (2015). Hubungan Asupan

Purin, Vitamin C dan Aktivitas Fisik

Terhadap Kadar Asam Urat Pada Remaja

Laki-Laki. Journal of Nutrition College,

Volume 4, 24-29.

https://doi.org/10.14710/jnc.v4i1.8617

Yenrina, R. (2014). Diet Sehat Untuk Penderita

Asam Urat. Penebar Swadaya.

Yong Park, D., Soo Kim, Y., Ho Ryu, S., \& Sun Jin, Y. (2019). The association between sedentary behavior, physical activity and hyperuricemia. Vascular Health and Risk Management, 15, 291-299.

https://doi.org/10.2147/VHRM.S200278 